\title{
Identifying global synchronies in marine zooplankton populations: issues and opportunities
}

\author{
R. Ian Perry, Harold P. Batchelder, David L. Mackas, Sanae Chiba, \\ Edward Durbin, Wulf Greve, and Hans M. Verheye
}

Perry, R. I., Batchelder, H. P., Mackas, D. L., Chiba, S., Durbin, E., Greve, W., and Verheye, H. M. 2004. Identifying global synchronies in marine zooplankton populations: issues and opportunities. - ICES Journal of Marine Science, 61: 445-456.

\begin{abstract}
Analyses of the influences of climate variability on local zooplankton populations and those within ocean basins are relatively recent (past 5-10 years). What is lacking are comparisons of zooplankton population variability among the world's oceans, in contrast to such global comparisons of fish populations. This article examines the key questions, capabilities, and impediments for global comparisons of zooplankton populations using long-term ( $>10$ year) data sets. The key question is whether global synchronies in zooplankton populations exist. If yes, then (i) to what extent are they driven by "bottomup" (productivity) or "top-down" (predation) forcing; (ii) are they initiated by persistent forcing or by episodic events whose effects propagate through the system with different time-lags; and (iii) what proportion of the biological variance is caused directly by physical forcing and what proportion might be caused by non-linear instabilities in the biological dynamics (e.g. through trophodynamic links)? The capabilities are improving quickly that will enable global comparisons of zooplankton populations. Several long-term sampling programmes and data sets exist in many ocean basins, and the data are becoming more available. In addition, there has been a major philosophical change recently that now recognizes the value of continuing long-term zooplankton observation programmes. Understanding of life-history characteristics and the ecosystem roles of zooplankton are also improving. A first and critical step in exploring possible synchrony among zooplankton from geographically diverse regions is to recognize the limitations of the various data sets. There exist several impediments that must be surmounted before global comparisons of zooplankton populations can be realized. Methodological issues concerned with the diverse spatial and temporal scales of "monitored" planktonic populations are one example. Other problems include data access issues, structural constraints regarding funding of international comparisons, and lack of understanding by decision-makers of the value of zooplankton as indicators of ecosystem change. We provide recommendations for alleviating some of these impediments, and suggest a need for an easily understood example of global synchrony in zooplankton populations and the relation of those signals to large-scale climate drivers.
\end{abstract}

(c) 2004 International Council for the Exploration of the Sea. Published by Elsevier Ltd. All rights reserved.

Keywords: biomass, climate, comparative approach, data access, global synchrony, methodology, phenology, predation, zooplankton.

Accepted 23 March 2004.

R. I. Perry: Fisheries and Oceans Canada, Pacific Biological Station, Nanaimo, B.C., V9T 6N7, Canada. H. P. Batchelder: College of Oceanic and Atmospheric Sciences, Oregon State University, Corvallis, OR, 97331-5503, USA. D. L. Mackas: Fisheries and Oceans Canada, Institute of Ocean Sciences, PO Box 6000, Sidney, B.C., V8L 4B2, Canada. S. Chiba: Frontier Research System for Global Change, 3173-25 Showa-machi, Kanazawa-ku, Yokohama, Japan. E. Durbin: Graduate School of Oceanography, University of Rhode Island, Narragansett, RI, 02882, USA. W. Greve: Forschungsinstitut Senckenberg, Notkestrasse 85, DE-22607 Hamburg, Germany. H. M. Verheye: Marine and Coastal Management, Private Bag X2, Rogge Bay 8012, Cape Town, South Africa. Correspondence to R. I. Perry: tel: +1 250756 7137; fax: + 1250756 7053; e-mail:perryi@pac.dfo-mpo.gc.ca

\section{Introduction}

Large-scale synchrony of small pelagic fish populations has been recognized for the past 20 years (Kawasaki, 1983,
1992; Figure 1). The causes of such synchrony have been hotly debated, and include forcing by climate (acting directly on physical oceanographic characteristics or indirectly through lower trophic levels) and fishing. To help 

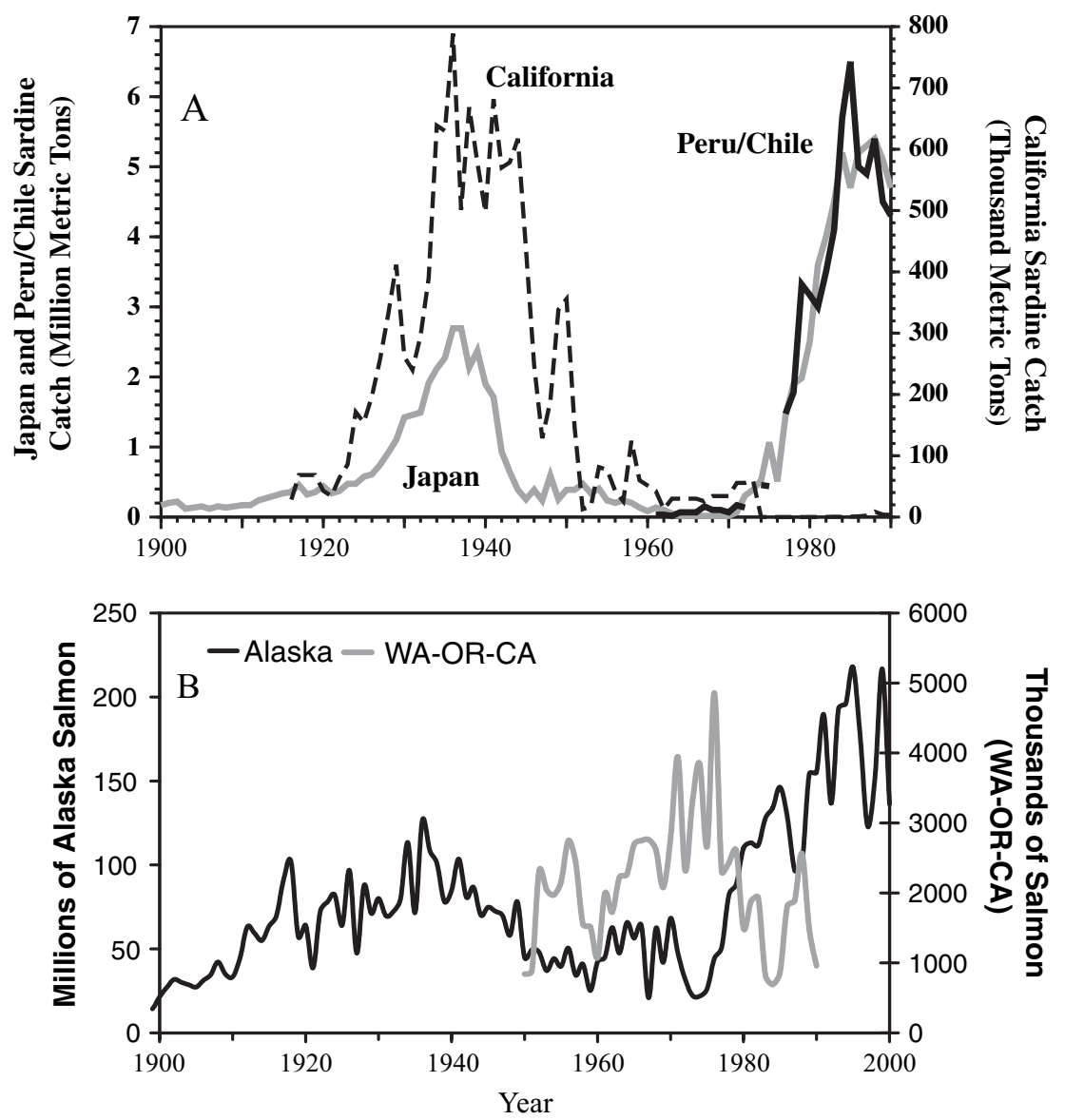

Figure 1. (A) Historical catch of Pacific sardine from the fisheries off Japan, California, and Peru-Chile (modified from Kawasaki (1992) updated with more recent catches). (B) Salmon catch in Alaska and Washington-Oregon-California (WA-OR-CA) regions of the Northeast Pacific. Figures are from Batchelder and Powell (2002). Salmon data are from Shepard et al. (1985), updated with catches through 1990. Post-1990 harvest of salmon in the WA-OR-CA region were restricted by regulation and are not shown.

resolve such issues, similar climate-population connections need to be investigated for zooplankton, which are a critical link in the web from climate to fish. Many of the "standard" climate indices now used by ocean researchers were defined in the past 10 years and compared to variations in local zooplankton populations, for example, the North Atlantic Oscillation (NAO; Hurrell, 1995; Planque and Reid, 1998), northern hemisphere temperature (NHT; Heyen et al. 1998; Beaugrand et al., 2002), Pacific Decadal Oscillation (PDO; Mantua et al., 1997; McGowan et al., 2003), and the Northern Oscillation Index (NOI; Schwing et al., 2002). Comparisons of zooplankton variations within ocean basins, and how they relate to these climate indices, are providing evidence that synchrony of zooplankton populations may occur over large spatial scales (e.g. Brodeur and Ware, 1992; Fromentin and Planque, 1996; Conversi et al., 2001; Batchelder et al., 2002; Beaugrand and Ibañez, 2002). Brodeur et al. (1996) found that interannual variations of zooplankton biomass at
Ocean Station $\mathrm{P}$ in the Subarctic Pacific and at offshore stations in the CalCOFI region of southern California were weakly negatively correlated. Beaugrand and Reid (2003) reported coherent temporal patterns of North Atlantic phytoplankton, zooplankton, and salmon with the North Atlantic Oscillation and northern hemisphere temperature. Zooplankton species composition has exhibited coherent shifts within the eastern North Pacific (Batchelder et al., 2002) and the North Atlantic (Beaugrand et al., 2002) basins. The next step after these within-ocean basin comparisons is to conduct a rigorous examination of zooplankton population variability (including biomass estimates, species composition, and phenology [timing of reproduction, life-history events, etc.; Greve, 2003]) among ocean basins on a global scale. But this has been slow and, as we shall describe, there are significant difficulties. The objectives of this article are to describe the motivation and key questions, the current capabilities, and the impediments to identifying whether marine zooplankton variations are 
synchronous at large (i.e. between ocean) scales, which will help to distinguish the factors causing large changes in global marine ecosystems.

\section{Key questions}

Several critical questions arise when comparing zooplankton data among ocean basins. These can be broadly grouped into two classes: (i) how to do such global comparisons; and (ii) why do such global comparisons. We begin with the scientific questions that should motivate global comparisons of zooplankton populations, and discuss the methodological issues later in the Impediments section.

Understanding the characteristics and drivers of longterm fluctuations of zooplankton populations on a global basis may provide opportunities for adaptive management that will maintain robust, healthy marine ecosystems. If large changes (e.g. regime shifts) in the productivity of the system occur, it is important to recognize them early in order to provide warnings to fishery and resource managers and potentially to adopt measures to mitigate the changes (or at least the impacts of the changes). Moreover, Taylor et al. (2002) suggest that subtle ecosystem effects of climate change may be amplified by complex biological interactions of the ecosystem. Thus, changes in zooplankton, or other biological constituents, may be better early indicators of regime shifts than physical changes.

\section{Global synchrony}

Does there appear to be global synchrony in marine zooplankton populations? This question has two important components: the definition of "synchrony", and which characteristics of zooplankton populations should be considered. Synchrony can include variations that are in phase, phased-shifted (time lagged), or of opposite phase. There are tantalising hints of synchrony in global zooplankton populations. For example, environmental shifts occurred in both the North Atlantic and North Pacific during the mid to late 1980s (Figure 2). These shifts were accompanied by changes in zooplankton (Mackas et al., 2001; Beaugrand and Reid, 2003). In the western North Pacific, zooplankton (Neocalanus) abundance increased after the late 1980s (Tadokoro et al., in press). A trend of increasing Calanus finmarchicus abundance in the Gulf of Maine during 1960-1990 (Conversi et al., 2001) was opposite to that of C. finmarchicus in the eastern North Atlantic and North Sea (Planque and Reid, 1998). In both instances, Calanus showed strong interdecadal trends that were related to the $\mathrm{NAO}$, but the long-term trends were of opposite sign on either side of the North Atlantic, suggesting that the NAO affects the circulation and temperature patterns of the western and eastern Atlantic in different ways (Conversi et al., 2001). However, Planque and Reid (1998) also point out the sometimes ephemeral nature of such climatezooplankton relationships.
Opposing long-term trends in zooplankton abundance (or biomass) have also been observed in different coastal upwelling systems over the past 4-5 decades (e.g. increasing in the Benguela Current vs. declining in the California, Guinea, and Humboldt Currents), despite the globally observed phenomenon of intensified wind-driven upwelling (Verheye, 2000). These and other studies suggest that some degree of synchrony in biomass and abundance occurs among geographically widely separated zooplankton populations. Beyond evidence of synchrony in biomass or abundance among zooplankton populations, there may be synchrony in other population aspects - such as life-history events related to seasonal migrations to the surface (e.g. phenology; Mackas et al., 1998), other seasonal responses (Greve et al., 2001), or changes in the rates of significant life-history processes. There is also the question of which component(s) of the zooplankton show global synchrony: the same species that occurs in different ocean basins; similar genera; guilds of species; or compositional changes in species assemblages. Therefore, the question "Is there synchrony among global marine zooplankton populations?" is more complex than simply comparing timeseries of biomass fluctuations, so that even if the initial answer appears to be "no", the problem warrants closer examination.

\section{Mechanisms causing synchrony}

If global synchrony is detected, then what are the responsible mechanisms? Is such synchrony related to climate variability acting directly on the zooplankton or does it occur through more complex bottom-up forcing via the foodweb? Fluctuations in zooplankton populations might also be related to predation (top-down forcing). This has been difficult to assess (Reid et al., 2000), except for simple systems with few alternative linkages (e.g. Daskalov, 2002). There are tantalising hints, however, such as zooplankton and pelagic fish in coastal upwelling systems (Cury et al., 2000), that suggest top-down control of zooplankton populations may be significant. In practice, zooplankton fluctuations are likely to occur as a result of both bottom-up and top-down forcing, therefore, a key question is how much of the observed zooplankton variation is due to each type of forcing (e.g. Verheye and Richardson, 1998; Verheye, 2000; Kang et al. 2002; Tadokoro et al., in press).

Zooplankton variations may also be due to rare or episodic events. Once such an event has occurred, its effects may propagate up (or down) the foodweb with a (perhaps unknown) time or spatial lag. Examples include storms (Peterson et al., 2002) and introduced non-indigenous species such as have been observed in the Black Sea (Shiganova, 1998). These are inherently local processes with (initially) small spatial scales, and the time-lags from perturbation to response may make identification of the initial perturbation almost impossible. If episodic events are important drivers of zooplankton variability generally, they 


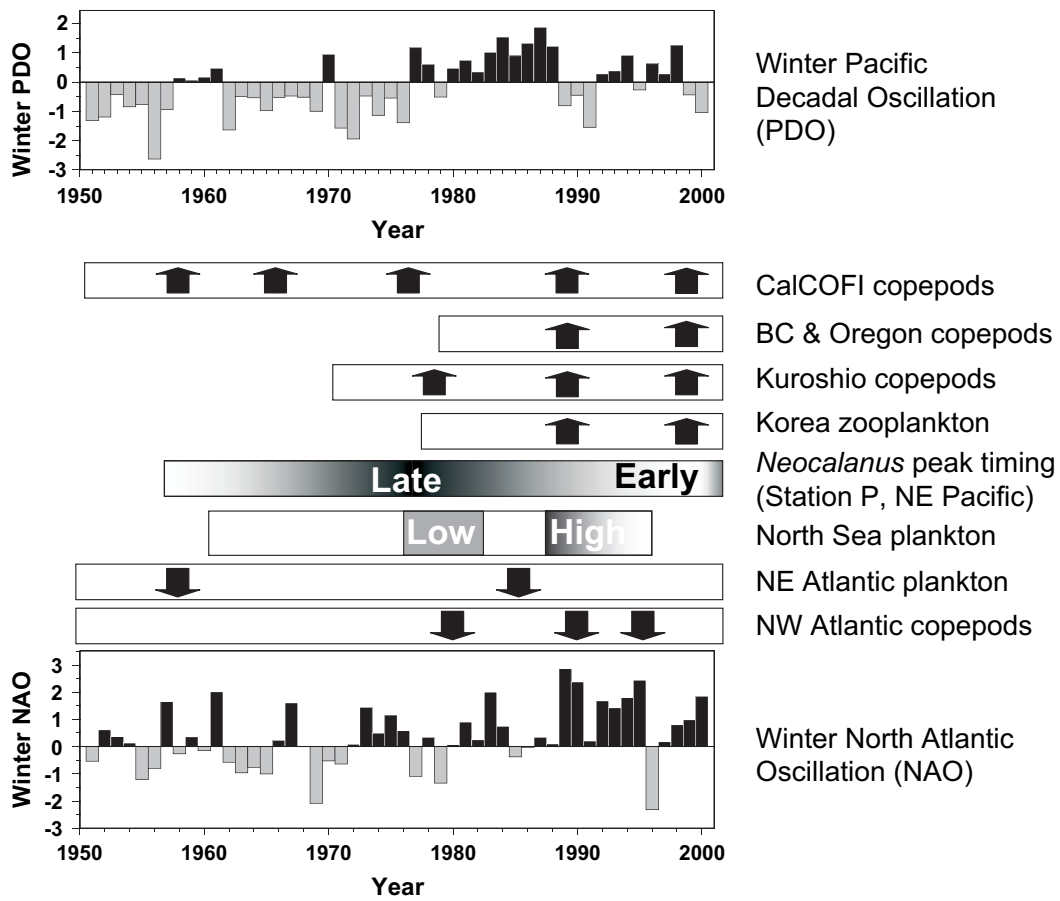

Figure 2. Schematic drawing showing North Pacific (PDO) and North Atlantic (NAO) climate indices, and timing of changes in the trends of plankton abundance and phenology time-series. Arrows indicate time of change, not direction of change. Data are from: CalCOFI (Rebstock, 2002a, b; McGowan et al., 2003); BC and Oregon (Mackas et al., in press); winter season Kuroshio region (Nakata and Hidaka, 2003); Korea (Kang, et al., 2002); Neocalanus peak timing (Mackas et al., 1998); North Sea plankton (Edwards et al., 2002); NE Atlantic plankton (Beaugrand and Reid, 2003); NW Atlantic copepods (Jossi et al., 2003).

will complicate the interpretation of globally forced coherence (such as by climate) in zooplankton time-series.

\section{Capabilities}

To conduct an analysis of global synchrony of zooplankton populations requires many long-term data sets from a variety of locations around the world. Fortunately, several data sets with 10 or more years of continuous data do exist (Table 1). Foremost among these are two programmes that have conducted spatially extensive zooplankton sampling for more than 50 years - one each from the Atlantic and Pacific. In the North Atlantic, the Continuous Plankton Recorder (CPR) programme has been in operation using similar methods since 1931 (Reid et al., 2003). In the North Pacific, the California Cooperative Oceanic Fisheries Investigation (CalCOFI) programme has been sampling zooplankton off California since 1951. Both have been used to explore regional relationships between climate forcing and zooplankton populations (Colebrook, 1978; Chelton et al., 1982; Roemmich and McGowan, 1995; Beaugrand et al., 2002; Edwards et al., 2002; Rebstock, 2002a). Other data sets that include spatially and temporally extensive sampling of zooplankton, but are less well analysed, exist for several eastern boundary current upwelling systems (e.g. the Benguela Current, the Humboldt Current, and the Guinea Current), the Black Sea, the Southern Ocean, and western and eastern sides of the North Pacific (Table 1). Several other programmes have conducted frequent sampling over extensive periods of time, but at only one or a few locations (Table 1).

A significant recent advance is that the data from many of these programmes are gradually becoming widely available, either through their own website (e.g. Station L4, English Channel: www.pml.ac.uk/L4) and/or by contributing data to the World Ocean Database (www.nodc.noaa. gov/OCL/plankton). International efforts such as the Global Ocean Data Archaeology and Rescue (GODAR) project are also helping to identify, recover, and provide access to historical zooplankton data, especially from large plankton collections held in laboratories of the former Soviet Union.

Recently, investigators have begun to move beyond single-species analyses to comparisons of changes in zooplankton community composition in relation to climate variability (e.g. Greve et al., 2001; Mackas et al., 2001; Beaugrand et al., 2002). Chiba and Saino (2003) relate zooplankton community composition in the Japan/East Sea to ENSO scale climate variations. When combined with changes in phenology (Mackas et al., 1998), such as the 
Table 1. Representative long time-series (with $\geq 10$ years of consecutive sampling) zooplankton observation programmes. More detailed compilations which include shorter time-series but for limited ocean regions are available in ICES (2003) and Alexander et al. (2001).

\begin{tabular}{|c|c|c|c|}
\hline Programme & Start and end years & Location & Source \\
\hline \multicolumn{4}{|l|}{ North Pacific } \\
\hline CalCOFI & 1949-continuing (quarterly) & California & www-mlrg.ucsd.edu/calcofi.html \\
\hline Station PAPA & $\begin{array}{l}\text { 1956-continuing ( } 3 \text { times per } \\
\text { year) }\end{array}$ & North Pacific, $50^{\circ} \mathrm{N} 145^{\circ} \mathrm{W}$ & $\begin{array}{l}\text { Fulton (1983); Mackas et al. } \\
\text { (1998) }\end{array}$ \\
\hline Newport, OR, USA & $\begin{array}{l}\text { Intermittent since } 1969 \text {, } \\
\text { continuous since } 1996 \\
\text { ( } 5 \text { times per year) }\end{array}$ & $\begin{array}{l}\text { Offshore transect at } 44^{\circ} 39.1^{\prime} \mathrm{N} \\
\text { (Oregon) }\end{array}$ & Peterson and Keister (in press) \\
\hline Vancouver Island Shelf & 1985-continuing (annual) & $\begin{array}{l}\text { Southwest shelf of Vancouver } \\
\text { Island }\end{array}$ & Mackas et al. (2001) \\
\hline Odate plankton time-series & 1951-continuing (monthly) & $\begin{array}{l}\text { Western North Pacific } \\
\text { (Kuroshio, Oyashio, and } \\
\text { transition region east of Japan) }\end{array}$ & $\begin{array}{l}\text { Odate (1994); Tomosada and } \\
\text { Odate (1995); Tadokoro (2001) }\end{array}$ \\
\hline $\begin{array}{l}\text { Hokkaido University, Oshoro- } \\
\text { Maru time-series }\end{array}$ & 1953-2001 (annual) & $\begin{array}{l}\text { Western and central Subarctic } \\
\text { North Pacific, and Bering Sea } \\
\left(\text { mostly along } 180^{\circ} \mathrm{E}\right)\end{array}$ & $\begin{array}{l}\text { Sugimoto and Tadokoro (1997); } \\
\text { Kobari and Ikeda (2001a) }\end{array}$ \\
\hline $\begin{array}{l}\text { Japan Meteorological Agency } \\
\text { (JMA) }\end{array}$ & $\begin{array}{l}\text { 1967, 1972-continuing } \\
\text { (seasonal) }\end{array}$ & $\begin{array}{l}\text { Several transects in western } \\
\text { North Pacific (all around } \\
\text { Japanese waters) }\end{array}$ & $\begin{array}{l}\text { Chiba and Saino (2003); } \\
\text { Tadokoro et al. (in press) }\end{array}$ \\
\hline $\begin{array}{l}\text { National Research Institute of } \\
\text { Fisheries Science (Japan), fish } \\
\text { egg and larvae survey }\end{array}$ & 1971-continuing (annual) & $\begin{array}{l}\text { Western subtropical North } \\
\text { Pacific (including Kuroshio } \\
\text { region) }\end{array}$ & Nakata et al. (2001) \\
\hline $\begin{array}{l}\text { Hokkaido National Institute of } \\
\text { Fisheries, A line monitoring }\end{array}$ & $\begin{array}{l}\text { 1987-continuing ( } 5-8 \text { times } \\
\text { per year) }\end{array}$ & $\begin{array}{l}\text { Western Subarctic North Pacific } \\
\text { (Oyashio region) }\end{array}$ & $\begin{array}{l}\text { Saito et al. (1998); Kasai et al. } \\
\text { (2001) }\end{array}$ \\
\hline $\begin{array}{l}\text { National Fisheries Research and } \\
\text { Development Institute (Korea), } \\
\text { oceanographic survey }\end{array}$ & $\begin{array}{l}\text { 1965-continuing } \\
\text { ( } 6 \text { times per year) }\end{array}$ & Korean waters & Kang (2001); Kang et al. (2002) \\
\hline \multicolumn{4}{|l|}{ North Atlantic } \\
\hline $\begin{array}{l}\text { Continuous Plankton Recorder } \\
\text { (CPR) }\end{array}$ & 1931-continuing (monthly) & North Atlantic & www.sahfos.org \\
\hline Helgoland Roads & $\begin{array}{l}\text { 1974-continuing (daily to } \\
\text { weekly) }\end{array}$ & $\begin{array}{l}\text { Southern North Sea }\left(54.19^{\circ} \mathrm{N}\right. \\
\left.7.9^{\circ} \mathrm{E}\right)\end{array}$ & Greve et al. (1996) \\
\hline Dove Marine Laboratory & 1968-continuing & Central-west North Sea & Evans and Edwards (1993) \\
\hline $\begin{array}{l}\text { Stazione Zoologica Anton } \\
\text { Dohrn; Station MC }\end{array}$ & $\begin{array}{l}\text { 1984-continuing (weekly to } \\
\text { bi-weekly sampling) }\end{array}$ & $\begin{array}{l}\text { Gulf of Naples }\left(40^{\circ} 48.5^{\prime} \mathrm{N}\right. \\
\left.4^{\circ} 15^{\prime} \mathrm{E}\right)\end{array}$ & $\begin{array}{l}\text { Mazzochi and Ribera d'Alcala } \\
\text { (1995) }\end{array}$ \\
\hline $\begin{array}{l}\text { Station C, western } \\
\text { Mediterranean }\end{array}$ & 1985-1995 (weekly) & $\begin{array}{l}\text { Gulf of Tigullio, Ligurian Sea, } \\
\text { western Mediterranean }\end{array}$ & Licandro and Ibanez (2000) \\
\hline $\begin{array}{l}\text { Plymouth Marine Laboratory, } \\
\text { Station L4 }\end{array}$ & 1988-continuing (weekly) & Western English Channel & www.pml.ac.uk/L4 \\
\hline $\begin{array}{l}\text { Icelandic Monitoring } \\
\text { Programme }\end{array}$ & 1961-continuing (annual) & Transects radiating from Iceland & Ássthorson and Gislason (1995) \\
\hline Emerald Basin & $\begin{array}{l}\text { 1984-continuing } \\
\text { (twice per year) }\end{array}$ & Scotian Shelf, NW Atlantic & DFO (2000) \\
\hline $\begin{array}{l}\text { MARMAP and Follow-up } \\
\text { Programme }\end{array}$ & 1977-continuing (quarterly) & $\begin{array}{l}\text { NE United States continental } \\
\text { shelf }\end{array}$ & Sherman (1980) \\
\hline Station 2 & $\begin{array}{l}\text { 1972-1997; 2002-continuing } \\
\text { (weekly) }\end{array}$ & $\begin{array}{l}\text { Lower Narragansett Bay, RI, } \\
\text { USA }\end{array}$ & Deason and Smayda (1982) \\
\hline \multicolumn{4}{|l|}{ South Atlantic } \\
\hline $\begin{array}{l}\text { Cape Routine Area Monitoring } \\
\text { Programme, expanded in } \\
1961 \text { to Southern Routine } \\
\text { Area Monitoring Programme }\end{array}$ & $\begin{array}{l}\text { 1951-1961 (monthly), } \\
1961-1967 \text { (monthly) }\end{array}$ & $\begin{array}{l}\text { Western Cape coast of South } \\
\text { Africa }\left(32-34^{\circ} \mathrm{S}\right. \\
\left.16^{\circ} 30^{\prime}-18^{\circ} 15^{\prime} \mathrm{E}\right) \text {, } \\
\text { southwestern Cape coast of } \\
\text { South Africa }\left(32-38^{\circ} \mathrm{S}\right. \\
\left.15^{\circ} 30^{\prime}-22^{\circ} \mathrm{E}\right)\end{array}$ & $\begin{array}{l}\text { Verheye and Richardson (1998); } \\
\text { Verheye et al. (1998); Verheye } \\
\text { (2000) }\end{array}$ \\
\hline
\end{tabular}


Table 1 (continued)

\begin{tabular}{|c|c|c|c|}
\hline Programme & Start and end years & Location & Source \\
\hline $\begin{array}{l}\text { Pelagic Fish Stock Assessment } \\
\text { surveys }\end{array}$ & $\begin{array}{l}\text { 1983-continuing ( } 3 \text { times per } \\
\text { year) }\end{array}$ & $\begin{array}{l}\text { Most of South Africa's west and } \\
\text { south coasts }\left(28^{\circ} 30^{\prime} \mathrm{S} 27^{\circ} \mathrm{E}\right)\end{array}$ & $\begin{array}{l}\text { Verheye and Richardson (1998); } \\
\text { Verheye et al. (1998); Verheye } \\
\text { (2000) }\end{array}$ \\
\hline $\begin{array}{l}\text { Walvis Bay Routine Area } \\
\text { Monitoring Programme }\end{array}$ & 1957-1965 (monthly) & $\begin{array}{l}\text { Namibian coast, vicinity of } \\
\text { Walvis Bay }\left(21-24^{\circ} \mathrm{S}\right. \\
\left.12^{\circ} 30^{\prime}-14^{\circ} 30^{\prime} \mathrm{E}\right)\end{array}$ & $\begin{array}{l}\text { Kollmer (1963); } \\
\text { Unterüberbacher (1964) }\end{array}$ \\
\hline SWAPELS Programme & 1972-1989 (monthly) & $\begin{array}{l}\text { Namibian coast }\left(17^{\circ} 30^{\prime}-27^{\circ} \mathrm{S}\right. \\
\left.10^{\circ} 30^{\prime}-15^{\circ} \mathrm{E}\right)\end{array}$ & (Verheye et al., 1998) \\
\hline Elephant Island & 1977-continuing & $\begin{array}{l}\text { Elephant Island region of the } \\
\text { Antarctic Peninsula }\end{array}$ & $\begin{array}{l}\text { Siegel et al. (1997); Siegel et al. } \\
\text { (1998) }\end{array}$ \\
\hline \multicolumn{4}{|l|}{ South Pacific } \\
\hline IMARPE zooplankton sampling & 1964-continuing (seasonal) & Peru coast and continental shelf & Carrasco and Lozano (1989) \\
\hline $\begin{array}{l}\text { Antofagasta zooplankton } \\
\text { sampling }\end{array}$ & $1991-2003$ & Northern Chile coast & Escribano and Hidalgo (2000) \\
\hline IFOP zooplankton sampling & 1985-continuing (seasonal) & Northern Chile shelf & www.IFOP.cl \\
\hline
\end{tabular}

life-history processes mentioned above, these provide broader scope for comparing synchrony of zooplankton populations and communities than just abundance or biomass alone.

Institutional support for long-term plankton sampling programmes has been intermittent at best. The most compelling evidence of this is the recurring difficulty of maintaining time-series sampling for some of the longest and most valuable zooplankton series: the CPR programme in the North Atlantic, Station P in the North Pacific, and the CalCOFI programme. Funding problems, and the fact that it takes many years of sustained sampling to document lower frequency changes or regime shifts, have resulted in data gaps in space and time. However, recently there has been increased recognition of the value of long time-series studies of zooplankton, in particular because data from some of these long time-series have shown patterns clearly correlated with climate variability. Within the past 5 years, several marine science organizations have contributed to the establishment of a new CPR programme in the North Pacific (Batten et al., 2003). In the western North Pacific, frequent sampling (6-8 observations per year) is also being conducted in the Oyashio region (Saito et al., 1998; Kasai et al., 2001). There is an increased appreciation for the value of continuing these long-term observation programmes, perhaps as part of future Global Ocean Observing Systems (GOOS).

\section{Impediments}

Despite the improved capabilities just discussed, there remain impediments to detecting and understanding global synchrony in zooplankton variations. These impediments can be classified as issues of (i) access to data, (ii) methodology, (iii) life history, and (iv) structure, including incomplete global observations of zooplankton populations.

\section{Data access issues}

Foremost among these impediments are issues relating to access to data. This has two components: generating data by analysing the plankton samples and making the data broadly available. Many programmes, such as CalCOFI, the Odate collection from the western North Pacific (Odate, 1994), and the SWAPEL (South West Africa Pelagic Egg and Larval) surveys along the coast of Namibia from 1972 to 1989 still have thousands of zooplankton samples unanalysed in jars. Gross measurements such as displacement or settled volume may have been made, but taxonomic identifications are lacking. As the examples cited above indicate, changes in the zooplankton fauna are often compositional, e.g. a change from northern to southern species, rather than changes in overall zooplankton biomass. Retrospective analyses of zooplankton composition from existing sample collections are difficult to fund. Once samples have been analysed, there can be additional difficulties in making the data widely available, such as in publications that receive broad distribution or, recently, through web-accessible computer databases. Many zooplankton data sets are reported inadequately in the literature and are not submitted to repositories for long-term archival.

\section{Methodological issues}

Methodological problems are a major impediment to global comparisons of zooplankton data. They fall into two general categories: sampling and analysis. Sampling issues include the use of widely different gears for capturing zooplankton, ranging from simple ring-nets (with various mesh sizes, mouth diameters, and mouth-obstructing bridles) towed vertically (from various depths) to obliquely towed and depth-stratifying devices using sophisticated electronic environmental monitoring systems, to pumps 
and, most recently, visual (camera) and acoustic systems (e.g. Harris et al., 2000; Wiebe and Benfield, 2003). These different methods each have different selectivities for zooplankton. Moreover, the sampling design can interact with zooplankton behaviour, such as diel vertical migration and responses to environmental or food conditions, to affect the efficiency of capture. Often samples from night and day can be dramatically different, and these differences need to be considered in evaluating changes at longer time scales.

The frequency and time period of sampling also vary, from concentrating on a particular time (e.g. month) and place to once-a-season or once-a-year sampling for large monitoring programmes. How to compare data collected at daily, weekly, monthly, seasonal, and longer time scales is an important problem. To determine whether zooplankton populations from different oceans have coherent temporal patterns at annual and longer scales, multi-year changes in zooplankton biomass or composition must be "separated" from other, perhaps larger, sources of variability at various spatial and temporal (e.g. diel, seasonal, etc.) scales.

When one moves beyond measurements of biomass or volume to species composition, the similarity and consistency of taxonomic identifications in, and among, long-term programmes becomes important. Revisions of taxonomy are not uncommon and separation of a (formerly) single species into two species occurs frequently (e.g. Neocalanus; Miller, 1988). We can expect more detailed taxonomic distinctions to arise as analyses of zooplankton genetics continue to develop.

Once the samples have been collected and the zooplankton composition enumerated, there are many differences in how these data are analysed statistically. All long-term sampling programmes have gaps in time and space; the extent of these gaps and how they are handled during data analysis can complicate global comparisons among zooplankton data. Few fisheries data sets show statistical stationarity (Bakun, 2001), in which properties such as the mean and variance remain constant over time, and there is no reason to expect zooplankton time-series to be any different. Statistical approaches such as adjustments for autocorrelation (Pyper and Peterman, 1998; Planque, 2000), ensemble averaging, filtering methods (Licandro et al., 2001), or calculations of anomalies from a regional climatology (even development of the climatology itself) are crucial for separating multi-year changes from other sources of variability (e.g. seasonal, spatial), but their application can differ greatly among programmes in different locations.

\section{Life-history issues}

Global comparisons of zooplankton population dynamics are hindered by inadequate understanding of the life histories and ecosystem processes of zooplankton. For example, the cues that induce and end diapause in copepods are still largely unknown (Dahms, 1995). Diapause transition, and the changes in depth distribution that result, will impact measured abundances. Also unknown is the extent to which species' responses to these cues are flexible (e.g. Mackas et al., 1998). As with fish life histories, the wide range of sizes that zooplankton go through as they develop from egg to adult complicates understanding of what controls zooplankton recruitment to the reproductive adult stage.

\section{Structural issues}

Organizational support for long-term zooplankton studies and their global comparisons is generally lacking, but is needed. The importance and relevance of long-term zooplankton data are not understood by many decision-makers and funding agencies. In contrast to fisheries, there is no mandated requirement to sample zooplankton. For example, Directive 2000/60/EC of the European Parliament (dated 23 October 2000) established a legal framework for Community action in the field of water policy. This framework required sampling of phytoplankton, benthic invertebrates, and fish, but not zooplankton. The consequence of not requiring zooplankton observations means that zooplankton observations will likely not be made in the context of this policy. This will reduce organizational support for zooplankton sampling, with the result that insights into climate and anthropogenic forcing of zooplankton variations and early warning of substantial temporal shifts of aquatic and marine systems will be harder to achieve. There are also few, if any, formal procedures to encourage and fund collaborative comparisons of zooplankton time-series data collected from multiple sites worldwide; each national funding agency has specific guidelines and schedules for funding scientific projects.

\section{Recommendations}

In order to address the key questions identified above and to encourage and facilitate global comparisons of long-term zooplankton data, we recommend the following:

i Existing at-risk zooplankton data must be protected from loss by submitting them to appropriate long-term data repositories.

ii Selective (cost-effective) samples from existing longterm zooplankton collections (in jars) should be analysed for species composition.

iii Rigorous intercalibrations should be conducted to document gear and sampling design differences and develop conversion factors.

iv "Voucher" specimens (and samples) preserved in ethanol for resolution of taxonomic issues should be retained.

v A common set of statistical and visualization methods should be developed and made widely available.

vi There should be greater emphasis on between-species and between-region comparisons of zooplankton lifehistories. 
vii There should be broad publication of the results of plankton monitoring programmes, especially those that link temporal fluctuations to environmental or fisheries conditions to demonstrate the value of zooplankton observations as ecosystem indicators that may provide early warning of shifts in ocean ecosystems.

\section{Data access issues}

Protecting existing data from loss (e.g. moving data from written documents in filing cabinets to computer archives) is clearly the top priority. Analysed data need to be submitted to, and made available through, a central data repository. One such repository is the World Ocean Database at the US National Oceanographic Data Center (www.nodc.noaa.gov/OCL/plankton), which archives data produced by various levels of processing and with various degrees of confidentiality. It is the responsibility of those in charge of zooplankton programmes to ensure this is done, and programmes such as the Global Oceanographic Data Archaeology and Rescue (GODAR) are available to help with recovery of old data.

A further key requirement is to process samples that have been collected but remain unanalysed in jars. Considering the huge number of such samples, this will be a major and expensive task, and for complete analysis it may have to wait for machine-automated or new genomic methods. Targeted processing of subsamples could be an alternative for specific global comparison projects. Statistical analyses of spatial and temporal autocorrelation scales should be undertaken to guide such subsampling, so that retrospective studies are done efficiently.

\section{Methodological issues}

One approach to resolving issues relating to different sampling techniques is to develop and promote a standardized protocol. This approach has been advocated by the Joint Global Ocean Flux Study, which specified a sampling methodology to ensure data inter-comparability. However, this has the disadvantage of changing sampling techniques and therefore disrupting ongoing time-series for those programmes that are not using the standard approach. Moreover, it does not allow for the adoption of regionally specific optimal protocols. It is unrealistic to sample higher latitude regions, which are dominated by zooplankton with large individual body sizes, using the same small-mesh sampling gear that would be appropriate for tropical regions with small-bodied zooplankton. It would be better to conduct rigorous intercalibration experiments (e.g. Rebstock, 2002b; McKinnell and Mackas, 2003) to document gear-related differences and, to the extent possible, develop conversion factors among the different gears. It is also important that each time-series programme documents changes in sampling protocols.
With respect to taxonomic identification issues, potential identification problems need to be resolved, perhaps through planned comparisons among relevant laboratories. In addition, it would be useful if ongoing and future zooplankton observation programmes retained "voucher specimens" preserved in ethanol. These could be used later with future molecular and biochemical techniques to resolve issues of taxonomic consistency. It may even be desirable to retain entire zooplankton samples (or subsamples) for analyses by future methods. Stable isotope analyses can provide a different perspective on global ecosystem (foodweb structure) responses to climate forcing (Rau et al., 2003), but have not been examined in many collections.

For post-collection statistical analysis methods, we recommend that common visualization and statistical tools be developed. Such common methods made widely available would enable data gaps, autocorrelation issues, etc., in different programmes to be dealt with using consistent approaches. This task might be undertaken by one of the large data archive centres. Once developed, these statistical tools will need to be made user-friendly and broadly available.

\section{Life-history issues}

Analyses of time-series data will help to improve understanding of life history and ecosystem processes for zooplankton by identifying critical unknowns. These can then be investigated with a combination of time-series observations and directed process studies. The betweenspecies and between-region comparisons of copepod lifehistory strategies of Yamaguchi and Ikeda (2000) and Kobari and Ikeda $(1999,2001 b)$ are proving useful, but similar analyses are needed for other taxa and regions.

\section{Structural issues}

The first step towards improving recognition of the importance of zooplankton in marine systems, and of comparing global fluctuations of zooplankton, is to publish the results of plankton monitoring programmes in the primary literature. In particular, published comparisons of local zooplankton time-series with local (or large-scale) variations in physical conditions, climate, or fisheries can stimulate cross-basin and inter-ocean comparisons. Some of this is occurring, particularly within the CPR programme in the North Atlantic (Beaugrand et al., 2002; Beaugrand and Reid, 2003; and others) and with the long time-series from Station $\mathrm{P}$ and CalCOFI in the North Pacific (Brodeur and Ware, 1992; Roemmich and McGowan, 1995; Rebstock, 2002a). But, for many other regions, zooplankton sample analysis or publication of the results of time-series zooplankton sampling is lacking. Equally important is to preserve (archive) and make zooplankton time-series data widely accessible to encourage large-scale synthesis, and 
thereby generate support for long-term zooplankton sampling programmes within the scientific, and ultimately broader, community.

To increase understanding among funding agencies of the value of sustained zooplankton observation programmes, there is a need to: (1) document and publish the evidence that large-scale climate variability strongly impacts zooplankton populations and the potential mechanisms for these connections, and (2) demonstrate that observations of zooplankton, as might be implemented in ocean observing systems, will provide early recognition of shifts in ecosystem structure, and that these indicators are important for characterizing the state (ecosystem quality) of regional seas. It is also important that individual scientists communicate research findings in venues and through methods that the public and decision-makers understand.

With regard to the difficulties of funding global zooplankton comparisons, the Global Ocean Ecosystems Dynamics (GLOBEC) project, the North Pacific Marine Science Organization (PICES), the International Council for the Exploration of the Sea (ICES), and other intergovernmental and non-governmental organizations should play a large and active role in supporting dedicated workshops and providing a framework for these comparisons. Many of these organizations and programmes do have groups addressing different aspects of these questions, but none appear to be considering global comparisons as described here.

\section{Conclusions}

What is needed to facilitate global comparisons of zooplankton population fluctuations, and to understand what drives these fluctuations and their implications for the sustainability of marine systems, is an analysis similar to that done by Kawasaki $(1983,1992)$ for small pelagic fish stocks (Figure 1A). This analysis has spurred the imagination of fisheries biologists and generated much discussion and criticism on (1) how to do such comparisons, (2) the processes underlying such apparent synchrony, and (3) the relative roles of exploitation (fishery harvest) vs. environmental effects on temporal fluctuations. It has stimulated a great number of similar comparisons with other species of fish (e.g. Pacific salmon, Figure 1B). A global analysis for zooplankton, similar to that done for fish, from diverse regions of the world's oceans can be expected to be equally stimulating. There has not been a rigorous, statistically robust, and detailed inter-comparison of time-series changes of zooplankton populations from multiple sites in several ocean basins that would directly address the issue of global synchrony. An added advantage of examining zooplankton stocks for global synchrony is that there is no direct exploitation of zooplankton stocks (except for Antarctic krill), which removes one of the sources of direct forcing of marine population variability. As indicated in this article, there are many details and issues to be resolved before such an analysis is likely to be produced. However, the results will be worth the effort.

\section{Acknowledgements}

This article originated from a half-day workshop convened as part of the 3rd International Zooplankton Production Symposium, held on 19-23 May 2003 in Gijon, Spain. The workshop was attended by over 60 participants from 17 countries. We thank all of those who participated, in particular Peter Wiebe, Mark Ohman, Todd O'Brien, George Hunt, Juergen Alheit, and Anthony Richardson. We also thank two anonymous reviewers whose comments substantially improved this manuscript. This is contribution number 416 of the U.S. GLOBEC programme, jointly funded by the National Science Foundation and National Oceanic and Atmospheric Administration. HPB acknowledges the support of NSF Grant OCE-0002047. RIP acknowledges the support of PICES for travel to this symposium.

\section{References}

Alexander, V., Bychkov, A. S., Livingston, P., and McKinnell, S. M. (Eds.) 2001. Proceedings of the PICES/CoML/IPRC workshop on "Impact of Climate Variability on Observations and Prediction of Ecosystem and Biodiversity Changes in the North Pacific". PICES Scientific Report, 18. 210 pp.

Ássthorson, O. S., and Gislason, A. 1995. Long-term changes in zooplankton biomass in Icelandic waters in spring. ICES Journal of Marine Science, 52: 657-668.

Bakun, A. 2001. "School-mix feedback": a different way to think about low frequency variability in large mobile fish populations. Progress in Oceanography, 49: 485-511.

Batchelder, H. P., Barth, J. A., Kosro, P. M., Strub, P. T., Brodeur, R. D., Peterson, W. T., Tynan, C. T., Ohman, M. D., Botsford, L. W., Powell, T. M., Schwing, F. B., Ainley, D. G., Mackas, D. L., Hickey, B. M., and Ramp, S. R. 2002. The GLOBEC Northeast Pacific California Current System Program. Oceanography, 15: 36-47.

Batchelder, H. P., and Powell, T. M. 2002. Physical and biological conditions and processes in the northeast Pacific Ocean. Progress in Oceanography, 53: 105-114.

Batten, S. D., Welch, D. W., and Jonas, T. 2003. Latitudinal differences in the duration of development of Neocalanus plumchrus copepodites. Fisheries Oceanography, 12: 201-208.

Beaugrand, G., and Ibañez, F. 2002. Spatial dependence of calanoid copepod diversity in the North Atlantic Ocean. Marine Ecology Progress Series, 232: 197-211.

Beaugrand, G., and Reid, P. C. 2003. Long-term changes in phytoplankton, zooplankton and salmon related to climate. Global Change Biology, 9: 801-817.

Beaugrand, G., Reid, P. C., Ibanez, F., Lindley, J. A., and Edwards, M. 2002. Reorganization of North Atlantic marine copepod biodiversity and climate. Science, 296: 1692-1694.

Brodeur, R. D., Frost, B. W., Hare, S. R., Francis, R. C., and Ingraham, W. J. Jr. 1996. Interannual variations in zooplankton biomass in the Gulf of Alaska, and covariation with California Current zooplankton biomass. CalCOFI Reports, 37: $80-99$. 
Brodeur, R. D., and Ware, D. M. 1992. Long-term variability in zooplankton biomass in the Subarctic Pacific Ocean. Fisheries Oceanography, 1: 32-38.

Carrasco, S., and Lozano, O. 1989. Seasonal and long-term variations of zooplankton volumes in the Peruvian Sea, 1964-1987. The Peruvian Upwelling Ecosystem: Dynamics and Interactions. ICLARM Conference Proceedings, 18, pp. 82-85. Ed. by D. Pauly, P. Muck, J. Mendo, and I. Tsukayama.

Chelton, D. B., Bernal, P. A., and McGowan, J. A. 1982. Largescale interannual physical and biological interaction in the California Current. Journal of Marine Research, 40: 1095-1125.

Chiba, S., and Saino, T. 2003. Variation in mesozooplankton community structure in the Japan/East Sea (1991-1999) with possible influence of the ENSO scale climatic variability. Progress in Oceanography, 57: 317-339.

Colebrook, J. M. 1978. Continuous plankton records: zooplankton and environment, North East Atlantic and North Sea, 19481975. Oceanologica Acta, 1: 9-23.

Conversi, A., Piontkovski, S., and Hameed, S. 2001. Seasonal and interannual dynamics of Calanus finmarchicus in the Gulf of Maine (Northeastern US shelf) with reference to the North Atlantic Oscillation. Deep-Sea Research II, 48: 519-530.

Cury, P., Bakun, A., Crawford, R. J. M., Jarre, A., Quiñones, R., Shannon, L. J., and Verheye, H. M. 2000. Small pelagics in upwelling systems: patterns of interaction and structural changes in "wasp-waist" ecosystems. ICES Journal of Marine Science, 57: $603-618$.

Dahms, H. U. 1995. Dormancy in the Copepoda - an overview. Hydrobiologia, 306: 199-211.

Daskalov, G. M. 2002. Overfishing drives a trophic cascade in the Black Sea. Marine Ecology Progress Series, 225: 53-63.

Deason, E. E., and Smayda, T. J. 1982. Ctenophore-zooplanktonphytoplankton interactions in Narragansett Bay, Rhode Island, USA during 1972-1977. Journal of Plankton Research, 4: 203-217.

DFO. 2000. State of the phytoplankton, zooplankton and krill on the Scotian Shelf in 1998. DFO Science Stock Status Report G3-02 (2000).

Edwards, M., Beaugrand, G., Reid, P. C., Rowden, A. A., and Jones, M. B. 2002. Ocean climate anomalies and the ecology of the North Sea. Marine Ecology Progress Series, 239: 1-10.

Escribano, R., and Hidalgo, P. 2000. Influence of El Niño and La Niña on the population dynamics of Calanus chilensis in the Humboldt Current ecosystem of northern Chile. ICES Journal of Marine Science, 57: 1867-1874.

Evans, F., and Edwards, A. 1993. Changes in the zooplankton community off the coast of Northumberland between 1969 and 1988, with notes on changes in the phytoplankton and the benthos. Journal of Experimental Marine Biology and Ecology, 172: $11-31$.

Fromentin, J. M., and Planque, B. 1996. Calanus and environment in the eastern North Atlantic. II. Influence of the North Atlantic Oscillation on C. finmarchicus and C. helgolandicus. Marine Ecology Progress Series, 134: 111-118.

Fulton, J. 1983. Seasonal and annual variations of net zooplankton at Ocean Station "P", 1956-1980. Canadian Data Report of Fisheries and Aquatic Sciences No. 374. 65 pp.

Greve, W. 2003. Aquatic plants and animals. In Phenology: an Integrative Environmental Science, pp. 385-403. Ed. by M. D. Schwartz. Kluwer, Amsterdam.

Greve, W., Lange, U., Reiners, F., and Nast, J. 2001. Predicting the seasonality of North Sea zooplankton. Senckenbergiana maritima, 31: 263-268.

Greve, W., Reiners, F., and Nast, J. 1996. Biocoenotic changes of the zooplankton in the German Bight: the possible effects of eutrophication and climate. ICES Journal of Marine Science, 53: 951-956.
Harris, R. P., Wiebe, P. H., Lenz, J., Skjoldal, H. R., and Huntley, M. (Eds). 2000. ICES Zooplankton Methodology Manual. Academic Press, San Diego. 684 pp.

Heyen, H., Fock, H., and Greve, W. 1998. Detecting relationships between the interannual variability in ecological time series and climate using a multivariate statistical approach - a case study on Helgoland Roads zooplankton. Climate Research, 10: 179-191.

Hurrell, J. W. 1995. Decadal trends in the North Atlantic Oscillation: regional temperatures and precipitations. Science, 269: 676-679.

ICES. 2003. Report of the Working Group on Zooplankton Ecology. ICES CM 2003/C: 01. 56 pp.

Jossi, J. W., John, A. W. G., and Sameoto, D. 2003. Continuous Plankton Recorder sampling off the east coast of North America: history and status. Progress in Oceanography, 58: 313-325.

Kang, Y. S. 2001. Monitoring system and long-term trend of zooplankton in the Korean waters. PICES Scientific Report, 18: $111-113$.

Kang, Y. S., Kim, J. Y., Kim, H. G., and Park, J. H. 2002. Long-term changes in zooplankton and its relationship with squid, Todarodes pacificus, catch in Japan/East Sea. Fisheries Oceanography, 11: 337-346.

Kasai, H., Saito, H., Kashiwai, M., Taneda, T., Kusaka, A., Kawasaki, Y., Kono, T., Taguchi, S., and Tsuda, A. 2001. Seasonal and interannual variations in nutrients and plankton in the Oyashio region: a summary of a 10 years observation along A-line. Bulletin of Hokkaido National Fisheries Research Institute, 65: 55-134.

Kawasaki, T. 1983. Why do some pelagic fishes have wide fluctuations in their numbers? In: Sharp, G.D., and Csirke, J. (Eds.), Proceedings of the Expert Consultation to examine changes in abundance and species of neritic fish resources. FAO Fisheries Report, 291: 1065-1080.

Kawasaki, T. 1992. Mechanisms governing fluctuations in pelagic fish populations. South African Journal of Marine Science, 12: 873-879.

Kobari, T., and Ikeda, T. 1999. Vertical distribution, population structure and life cycle of Neocalanus cristatus (Crustacea: Copepoda) in the Oyashio region, with notes on its regional variations. Marine Biology, 134: 683-696.

Kobari, T., and Ikeda, T. 2001a. $180^{\circ}$ longitude - oceanographic time-series information. PICES Scientific Report, 18: 114-118.

Kobari, T., and Ikeda, T. 2001b. Life cycle of Neocalanus flemingeri (Crustacea: Copepoda) in the Oyashio region, western Subarctic Pacific, with notes on its regional variations. Marine Ecology Progress Series, 209: 243-255.

Kollmer, W. E. 1963. Notes on zooplankton and phytoplankton collections made off Walvis Bay. Administration of South West Africa Marine Research Laboratory Investigational Report, 8: $1-78$.

Licandro, P., and Ibanez, F. 2000. Changes of zooplankton communities in the Gulf of Tigullio (Ligurian Sea, western Mediterranean) from 1985 to 1995 . Influence of hydroclimatic factors. Journal of Plankton Research, 22: 2225-2253.

Licandro, P., Conversi, A., Ibanez, F., and Jossi, J. 2001. Time series analysis of interrupted long-term data set (1961-1991) of zooplankton abundance in Gulf of Maine (northern Atlantic, USA). Oceanologica Acta, 24: 453-466.

Mackas, D. L., Goldblatt, R., and Lewis, A. G. 1998. Interdecadal variation in developmental timing of Neocalanus plumchrus populations at Ocean Station P in the Subarctic North Pacific. Canadian Journal of Fisheries and Aquatic Sciences, 55: 1878-1893.

Mackas, D. L., Peterson, W. T., and Zamon, J. Comparisons of interannual biomass anomalies of zooplankton communities along the continental margins of British Columbia and Oregon. Deep-Sea Research II (in press). 
Mackas, D. L., Thomson, R. E., and Galbraith, M. 2001. Changes in the zooplankton community of the British Columbia continental margin, 1985-1999, and their covariation with oceanographic conditions. Canadian Journal of Fisheries and Aquatic Sciences, 58: 685-702.

Mantua, N. J., Hare, S. R., Zhang, Y., Wallace, J. M., and Francis, R. C. 1997. A Pacific interdecadal climate oscillation with impacts on salmon production. Bulletin of the American Meteorological Society, 78: 1069-1079.

Mazzochi, M. G., and Ribera d'Alcala, M. 1995. Recurrent patterns in zooplankton structure and succession in a variable coastal environment. ICES Journal of Marine Science, 52: 671-691.

McGowan, J. A., Bograd, S. J., Lynn, R. J., and Miller, A. J. 2003. The biological response to the 1977 regime shift in the California Current. Deep-Sea Research II, 50: 2567-2582.

McKinnell, S. M., and Mackas, D. L. 2003. Intercalibrating SCOR, NORPAC, and bongo nets and the consequences for interpreting decadal-scale variation in zooplankton biomass in the Gulf of Alaska. Fisheries Oceanography, 12: 126-133.

Miller, C. B. 1988. Neocalanus flemingeri, a new species of Calanidae (Copepoda: Calanoida) from the Subarctic Pacific Ocean, with a comparative redescription of Neocalanus plumchrus (Marukawa) 1921. Progress in Oceanography, 20: 223-273.

Nakata, K., and Hidaka, K. 2003. Decadal-scale variability in the Kuroshio marine ecosystem in winter. Fisheries Oceanography, 12: $234-244$.

Nakata, K., Koyama, S., and Matsukawa, Y. 2001. Interannual variation in spring biomass and gut content composition of copepods in the Kuroshio current, 1971-89. Fisheries Oceanography, 10: 329-341.

Odate, K. 1994. Zooplankton biomass and its long-term variation in the western North Pacific Ocean, Tohoku Sea Area, Japan. Bulletin of Tohoku National Fisheries Research Institute, 56: 115-173.

Peterson, W. T., and Keister, J. E. Interannual variability in copepod community composition at a coastal station in the northern California Current: a multivariate approach. Deep-Sea Research II (in press).

Peterson, W. T., Keister, J. E., and Feinberg, L. R. 2002. The effects of the 1997-99 El Niño events on hydrography and zooplankton off the central Oregon coast. Progress in Oceanography, 54: 381-398.

Planque, B. 2000. Retrospective analysis, pitfalls and solutions serial correlation. GLOBEC International Newsletter, 6(2): $23-24$.

Planque, B., and Reid, P. C. 1998. Predicting Calanus finmarchicus abundance from a climatic signal. Journal of the Marine Biological Association of the United Kingdom, 78: 1015-1018.

Pyper, B. J., and Peterman, R. M. 1998. Comparison of methods to account for autocorrelation in correlation analyses of fish data. Canadian Journal of Fisheries and Aquatic Sciences, 55: 2127-2140.

Rau, G. H., Ohman, M. D., and Pierrot-Bults, A. 2003. Linking nitrogen dynamics to climate variability off central California: a 51 -year record based on ${ }^{15} \mathrm{~N} /{ }^{14} \mathrm{~N}$ in CalCOFI zooplankton. Deep-Sea Research II, 50: 2431-2447.

Rebstock, G. A. 2002a. Climatic regime shifts and decadal-scale variability in calanoid copepod populations off southern California. Global Change Biology, 8: 71-89.

Rebstock, G. A. 2002b. An analysis of a zooplankton samplinggear change in the CalCOFI long-term monitoring program, with implications for copepod population abundance trends. Progress in Oceanography, 53: 215-230.

Reid, P. C., Battle, E. J. V., Batten, S. D., and Brander, K. M. 2000. Impacts of fisheries on plankton community structure. ICES Journal of Marine Science, 57: 495-502.
Reid, P. C., Colebrook, J. M., Matthews, J. B. L., and Aiken, J. et al., 2003. The Continuous Plankton Recorder: concepts and history, from plankton indicator to undulating recorders. Progress in Oceanography, 58: 117-173.

Roemmich, D., and McGowan, J. 1995. Climate warming and the decline of zooplankton in the California Current. Science, 267: 1324-1326.

Saito, H., Kasai, H., Kashiwai, M., Kawasaki, Y., Kono, T., Taguchi, S., and Tsuda, A. 1998. General description of seasonal variations in nutrients, chlorophyll $a$, and net plankton biomass along the A-line transect, western Subarctic Pacific, from 1990 to 1994. Bulletin of Hokkaido National Fisheries Research Institute, 62: 1-62.

Schwing, F. B., Murphree, T., and Green, P. M. 2002. The Northern Oscillation Index (NOI): a new climate index for the northeast Pacific. Progress in Oceanography, 53: 115-139.

Shepard, M. P., Shepard, C. D., and Argue, A. W. 1985. Historic statistics of salmon production around the Pacific rim. Canadian Manuscript Report of Fisheries and Aquatic Sciences, 1819: $297 \mathrm{pp}$.

Sherman, K. 1980. MARMAP, a fisheries ecosystem study in the northwest Atlantic: fluctuations in ichthyoplanktonzooplankton components and their potential for impact on the system. In Advanced Concepts in Ocean Measurements for Marine Biology. Ed. by F. P. Diemer, F. J. Vernberg, and D. Z. Mirkes. Belle W. Baruch Institute of Marine Biology and Coastal Research, Georgetown, South Carolina, USA.

Shiganova, T. A. 1998. Invasion of the Black Sea by the ctenophore Mnemiopsis leidyi and recent changes in pelagic community structure. Fisheries Oceanography, 7: 305-310.

Siegel, V., Loeb, V., and Groeger, J. 1998. Krill (Euphausia superba) density, proportional and absolute recruitment and biomass in the Elephant Island region (Antarctic Peninsula) during the period 1977 to 1997. Polar Biology, 19: 393-398.

Siegel, V., De la Mare, W. K., and Loeb, V. 1997. Long-term monitoring of krill recruitment and abundance indices in the Elephant Island area (Antarctic Peninsula). CCAMLR Science, 4: $19-35$.

Sugimoto, T., and Tadokoro, K. 1997. Interannual-interdecadal variations in zooplankton biomass, chlorophyll concentration and physical environment in the Subarctic Pacific and Bering Sea. Fisheries Oceanography, 6: 74-93.

Tadokoro, K. 2001. Long-term variations of plankton biomass in the North Pacific. PICES Scientific Report, 18: 132-136.

Tadokoro, K., Chiba, S., Ono, T., Midorikawa, T., and Saino, T. Interannual variations of Neocalanus copepod biomass in the Oyashio water, western Subarctic North Pacific. Fisheries Oceanography (in press).

Taylor, A. H., Allen, J. I., and Clark, P. A. 2002. Extraction of a weak climatic signal by an ecosystem. Nature, 416: 629-632.

Tomosada, A., and Odate, K. 1995. Long-term variability in zooplankton biomass and environment. Umi to Sora, 71: $1-7$. (in Japanese with English abstract).

Unterüberbacher, H. K. 1964. Zooplankton studies in the waters off Walvis Bay with special reference to the Copepoda. Administration of South West Africa Marine Research Laboratory Investigational Report, 11: 1-42.

Verheye, H. M. 2000. Decadal-scale trends across several marine trophic levels in the southern Benguela upwelling system off South Africa. Ambio, 29: 30-34.

Verheye, H. M., and Richardson, A. J. 1998. Long-term increase in crustacean zooplankton abundance in the southern Benguela upwelling region, 1951-1996: bottom-up or top-down control? ICES Journal of Marine Science, 5: 803-807.

Verheye, H. M., Richardson, A. J., Hutchings, L., Marska, G., and Gianakouras, D. 1998. Long-term trends in the abundance and community structure of coastal zooplankton in the southern 
Benguela system, 1951-1996. South African Journal of Marine Science, 19: 317-332.

Wiebe, P. H., and Benfield, M. C. 2003. From the Hensen net toward four-dimensional biological oceanography. Progress in Oceanography, 56: 7-136.
Yamaguchi, A., and Ikeda, T. 2000. Vertical distribution, life cycle, and developmental characteristics of the mesopelagic calanoid copepod Gaidius variabilis (Aetideidae) in the Oyashio region, western North Pacific Ocean. Marine Biology, 137: 99-109. 